\title{
Legal approaches to the burial rights of a surviving wife
}

\author{
by Dr Remigius N Nwabueze
}

\section{INTRODUCTION}

$\mathrm{M}$ ost mortuary cultures sentimentalise the dead body of a departed relative (Richardson, 2006). Legal systems accommodate these sentiments through the development of appropriate legal protections. But the task of couching the needed protection in precise legal terms and categories has proved to be a daunting exercise. For instance, even though nervous shock is not generally remediable in English law, the English Court of Appeal had to grapple with the propriety of remedying shock (in damages) resulting from the disturbance of a coffin enclosing a dead body when the hearse carrying it was involved in an accident (Owens $v$ Liverpool Corporation [1939] $1 \mathrm{~KB}$ 394). In Louisville \& NR Co $v$ Wilson, 51 S.E. 24, 25; Ga. 1905, a US court captured the enormity of the legal challenge posed by dead bodies:

"Death is unique. It is unlike aught else in its certainty and its incidents. A corpse in some respects is the strangest thing on earth. A man who but yesterday breathed, and thought, and walked among us has passed away. Something has gone. The body is left still and cold, and is all that is visible to mortal eye of the man we knew. Around it cling love and memory. Beyond it may reach hope. It must be laid away. And the law - that rule of action which touches all humans - must touch also this thing of death. It is not surprising that the law relating to this mystery of what death leaves behind cannot be precisely brought within the letter of all rules regarding corn, lumber, and pig-iron."

The problem of legal regulation is probably felt more in the selection of the person entitled to determine the time, place and manner of burial of a deceased relative. More especially, do legal systems recognise the right of a surviving wife to control the disposition of her husband's remains? Much depends on the particular legal system. Sepulchral regimes vary significantly between the North and South and between western and non-western civilisations.

\section{WOMEN IN WESTERN LEGAL SYSTEMS}

Most western legal systems recognize the right of a surviving wife to control the disposition of the remains of her deceased husband. In the USA, the surviving wife is the appropriate person to determine the time, manner and place of burial of her deceased husband. Although she is expected to take the wishes of other members of the family into consideration, her own sepulchral wishes are controlling and paramount in the event of a conflict. In this way the prioritization of a widow's right to bury her deceased husband reinforces her pre-eminent status as the closest person to the deceased (at least formally). It also gives acute expression to the binding character of marriage and the precedence that it attracts in family relations. But the American widow is not given priority at all cost and in all circumstances. For instance, a widow's priority is subject to the burial wishes of her deceased husband. If the decedent's sepulchral wishes are ascertainable and clear, American courts will enforce them. Accordingly, the widow's priority is lost where the deceased husband gave particular directions regarding the disposition of his remains. Whether these mortuary directions were actually given and what their contents are would always remain questions of fact and the answer would depend on the surrounding circumstances of each case.

Nevertheless, an American man may make stipulations in his will regarding the manner of his burial and these will be given legal effect even though they are contrary to the wishes of the widow. It is also immaterial that the testamentary direction contradicts the hallowed proposition that the human body is not property in the ordinary sense of the term and, therefore, not capable of testamentary disposition. Moreover, burial directions in a will are likely to be enforced even though the will is invalid and unenforceable. Likewise, testamentary directions on disposition of remains may be revoked informally, without the execution of another will, codicil, or other written instrument. An American man may express his burial wishes in other forms apart from in a will; for instance, by filling relevant forms with a funeral home or by simply signing a written burial directive. Indeed, parol directions given by a decedent regarding the manner of his burial will be given effect against the contrary wishes of the surviving wife.

In addition to the overriding effect given to the deceased's wishes, an American widow will lose her 
sepulchral priority if she was divorced from the deceased at the time of his death. In some states in the USA, even mere judicial separation or evidence of bad relationship between the deceased and the surviving wife may engender loss of priority. These situations challenge the presumption of closeness and her claims to sentimental attachment (to the deceased) which sepulchral priority tries to vindicate. Except in the above circumstances, a surviving wife has the unquestionable right to control the disposition of her deceased husband to the exclusion of other people. As such, the American sepulchral framework is highly individualised but it has its advantages. It ensures that in the event of a family dispute (which is common these days) over the right to determine the time, manner and place of burial of the deceased (her husband), her decisional authority to do so is not in doubt. This certainty avoids unnecessary litigation between family members which would exacerbate the grief arising from the death of the husband. But this approach carries the disadvantage of insensitivity to the legitimate wishes of other family members who did not agree with the widow's general plan for burial. Where there is no love lost between a widow and her deceased husband's relatives, the paramountcy of her sepulchral right provides an opportunity for mischief; she could arrange burial at a time and place that guarantees the non-attendance of the deceased's relatives. She could also arrange burial in a manner that is religiously or culturally offensive to those relatives. For instance, she could authorise the cremation of her husband's remains in order to assault the sensibility of her in-laws (the deceased relatives) whose traditional or spiritual beliefs in life after death ordain burial of the body intact.

The position is not much different in the UK, Australia, and Canada. Sepulchral prioritisation in these jurisdictions is still marked by their individualisation. Paramountcy, however, is accorded to the wishes of the executor or the deceased's legal representative rather than the surviving wife, except she is also the deceased's executrix. It beats one's imagination why the executor rather than the surviving wife should have the decisional authority over the disposal of the remains of the deceased. This curiosity can only be satisfied by an excursion into legal history and by unpacking the common law's (mis)treatment of married women. Until 125 years ago, the English common law hardly regarded a married woman as having an identity separate from her husband. Her chattels were his. She could not have any estate of her own, except with a few equitable exceptions; and she was socially and practically considered to be her husband's property. In such an economic and social state, it would have been unwise for the common law to impose on her the duty of burying her husband which involved great financial outlay. It is no surprise that since her husband owned his wealth as well as hers, the common law imposed a duty on the husband to bury his wife (at least until recently) (Rees v Hughes [1946] $1 \mathrm{~KB} 517)$. On the husband's death, and the wife surviving him, his executor steps into his shoes for the purposes of administration. With the wherewithal to bear the funeral expenses, the executor assumes the duty of burial and the right that comes with it. For this reason, the funeral expenses are considered to be a first charge on the estate of the deceased. It would have been absurd to expect a surviving wife in the economic and legal conditions of $18^{\text {th }}$ century England to shudder the responsibility of burying her husband. So, the common law rule preferring the executor to the wife has deep historical underpinnings.

In practice, however, there is hardly any conflict. Most executors are sensitive to the wishes of the surviving wife. Except where the deceased gave burial directions which an executor feels morally obliged to comply with, the time, manner and place of burial will normally be chosen consistently with the wishes of the surviving spouse. But as regards strict legal interpretation, a surviving wife has no remedy against an executor who is determined to ignore her burial wishes in relation to her deceased husband. Indeed, the executor can even ignore the deceased's mortuary directions (Williams $v$ Williams [1882] $20 \mathrm{Ch} \mathrm{D}$ 659). The lot of the married woman improved a little bit with the passage of the Married Women's Property Act, 1882 (and similar statutes passed after that). That Act recognized a married woman as capable of owning property just like her husband; but it did not project her to sepulchral priority - it is still the executor's. If the Act had any impact in the burial realm, it was to relieve the husband of the duty of burying his wife (Rees $v$ Hughes). Since a wife can now have her own separate estate and property of her own, her funeral expenses are defrayed from her estate. Her new property status means that a married woman can validly make a will to dispose of her property and, for that purpose, to appoint an executor. Just like her husband, her executor has the duty of burying her and the right to determine the time, manner and place of her burial. She is now on equal footing with her husband. Where there is no executor and a dispute arises as to who is entitled to control the disposition of the remains of the deceased, some cases suggest that it is the legal representative or (absent that) the person entitled to be appointed the deceased's administrator or administratrix (Buchanan v Milton [1999] 2 FLR 844; Jones v Dodd [1999] 73 SASR 328; Smith v Tamworth City Council [1997] 41 NSWLR 680). The administration of estates laws of most countries give preference to the surviving wife in the choice of an administrator of the estate of the intestate. Such laws indirectly protect the right of a widow to control the disposition of her husband's remains. One thing, however, is clear. In the UK, USA, Canada, and Australia, the decisional authority over the burial of a family member is the prerogative of a single person. The framework of regulation is rights-based. In those jurisdictions, the individualisation of sepulchral rights is beyond cavil and it contrasts sharply with the position in many African countries. 


\section{SURVIVING WIVES IN AFRICA}

Burial regime in many African countries is group-based in contradistinction to the rights-based approach of most western legal systems. In most systems of customary law in Africa, no individual can claim the sole right to determine the time, place and manner of burial of a deceased family member. Burial is a family affair. The duty of burial belongs to the family as a whole. The head of a family has the responsibility of coordinating and managing the funeral arrangements for the burial of a deceased member. In some respects, the head of a family is like a trustee; he exercises the right of burial for the benefit of every family member. Since a woman cannot become the head of a family in many African countries, she is logically excluded from controlling the disposition of her husband's remains. There are a few exceptions though. For instance, among the Yorubas of western Nigeria a strong and influential senior female member of a family might be selected to head the family (Taiwo v. Sarumi [1913] 2 NLR 103; Elias, 1971, 104-05). Accordingly, where a woman's husband dies, the right of burial does not belong to her, but to the family of her deceased husband. In that case, the head of family may be a father, brother or uncle of the deceased. The surviving wife is obliged to acquiesce in the family's decision regarding burial. Her position is even more tenuous in some customary law systems where the surviving wife could be inherited by one of her husband's relatives.

It is at once obvious that the African group-based approach to sepulchral rights is problematical. It conflicts with notions of equality in constitutional democracies, as well as conflicting inexorably with the frameworks of most human rights instruments which reflect the rights-based possessive individualism of western civilisation (Macpherson, 1962). Moreover, the familial approach in Africa has its roots in customary law whose patriarchal origins naturally render it less receptive to women's rights. Sepulchral priority under customary is open to abuse. It might provide an opportunity for disgruntled in-laws to "settle scores" with a widow. It is not uncommon in many African countries that when a man dies and is survived by his wife (or only female children), his relatives swoop on his property under a claim of entitlement to his estate recognised by customary law. Thus, the widow is dispossessed and disinherited. There was even a Nigerian case where a widow was threatened by her father-in-law that unless she declared and relinquished claims to her husband's property she would be visited with the misfortune of leaving her husband's corpse in the rain and unburied (Moses, 2005).

A Kenyan Court of Appeal case brings these difficulties (under customary law) into bold relief. In Otieno v Ougo [1982-87] 1 KAR 1049, the claimant widow was a highprofile politician in Kenya while her deceased husband was a famous criminal lawyer. The husband died intestate and a dispute arose between the widow and her in-laws as to the place of interment. The widow wanted her husband to be buried in the city of Nairobi where both had lived and worked for many years. The deceased brothers and relatives wanted him to be buried in the village (ancestral home) in accordance with the customs of their people. The widow won at the trial court but the in-laws went to the Court of Appeal where the issue boiled down to which system of law was applicable, customary or English-type laws and legislation? The Kenyan Court of Appeal observed that it must be guided by customary law unless the application of customary law proved to be repugnant to justice and morality or inconsistent with a written law. According to the Court of Appeal, the main reason the received English common law was not applicable was because its application was subject to the limits of local circumstances under section 3 of the Judicature Act, cap 8 . Since there was a clear customary law relating to burial in Kenya, the Court of Appeal argued, "the common law will not fit the circumstances of Kenya" (1056). Even if the common law were applicable, the Court of Appeal further observed, the husband's executor rather than the claimant widow would be entitled to the right arising from the duty of burial (1058-1059). Since the deceased (husband) died intestate the claimant widow could not claim to be an executor (as there was no will appointing her an executrix); and her application for letters of administration having not been determined as at the time of the judgment of the Court of Appeal, she could not claim as an administratrix.

The Court of Appeal surmised that her application would invariably have failed even if customary law were not applicable. Under the applicable Luo customary law, burial is invariably in the village unless the deceased, during his life time, performed a particular customary ceremony which demonstrated his intention to be buried in a place other than his ancestral home (the ceremony was not performed in Otieno's case). On the argument that the deceased's western life-style, profession, sophistication and urbanisation took him out of the regulation of customary mortuary law, the Court of Appeal observed:

$$
\begin{aligned}
& \text { "At present there is no way in which an African citizen of } \\
& \text { Kenya can divest himself of the association with the tribe of } \\
& \text { his father if those customs are patrilineal. It is thus clear that } \\
& \text { Mr Otieno having been born and bred a Luo remained a } \\
& \text { member of the Luo tribe and subject to the customary law of } \\
& \text { the Luo people. The Luos are patrilineal people." (at 1054). }
\end{aligned}
$$

Accordingly, the Court of Appeal dismissed the widow's case and allowed her husband's relatives to bury him according to their customs and tradition. The case is often thought to be a sign of victory for the resilience of customary law, but it rather signals a progressive trend that will climax in the very near future: African women, especially the educated ones, are not likely to accept the regulation of a discriminatory system of customary law without question (Stamp, 1991; Doren, 1988). It should be said, however, that shorn of the exclusionary uses of the group-based approach to burial rights, the African 
mortuary priority system is superior to the rights-based approach in many western societies. Most family issues in Africa are based on negotiation and reconciliation; it is not a winner-takes-it-all approach characteristic of the possessive individualism of western democracies and their sepulchral regime. Under customary law, family cohesion is more important than the rights of individual members. Provided the wishes of an African widow are respected and factored into the burial equation, the disposition of the remains of her husband is likely to have a familial character that satisfies every member of the family. It will also be consistent with the belief in Africa that the death of a relative is a loss to the entire family.

\section{EXCLUDING CUSTOMARY MORTUARY LAW}

Otieno's case suggests that an African cannot opt-out (or contract out) of customary law except within the limits imposed by customary law, such as by performing a ceremony which evinces the celebrant's intention to be buried in a place of his choosing (other than his ancestral home). This statement, however, should be taken with some caution since the deceased in that case did not make a will and the court refused to accept the claimant's evidence relating to her husband's intention to be buried in the city of Nairobi. It seems that the application of customary law, including customary mortuary law, will be excluded by English-type transactions such as the making of a will (Nwabueze, 2002). In that case, the executor is the appropriate person to take charge of the deceased, and where the surviving wife is also the executrix, customary mortuary law will certainly pose no problem for her. She would simply use her right as an executrix to realise her own personal burial wishes. Secondly, where the deceased died intestate the surviving wife is preferred in the grant of letters of administration under the succession or administration of estate laws of most African countries. As an administratrix the law gives her the custody of the deceased for burial. A surviving wife in Africa wishing to exclude the application of customary mortuary rules is well-advised to get letters of administration. But the grant may not come in good time for burial, especially where the widow's application for letters of administration is opposed by her husband's relative, as in Otieno's case. In that case the Kenyan Court of Appeal held that while the widow would be preferred in the grant of letters of administration, she could not claim any right under it since the grant had not yet been made at the time of the action. In such circumstances, customary law will fill the gap, to the chagrin of the surviving wife.

The application of customary mortuary law could also be contested on constitutional grounds. A widow could argue that her exclusion by customary burial practices discriminate against her as a female. She could even argue that the right to bury her husband is a property right; its violation amounts to a deprivation of property under the constitution. This latter argument is likely to confront the common law rule that there is no property right in the dead body of a human being (Nwabueze, 2007). The equality argument or right against sex-based discrimination was raised in Otieno's case. The Court of Appeal, however, held that sections 82(3) and (4)(b) of the Kenyan Constitution expressly permit discriminatory burial rules (at 1060). This type of constitutional exemption is likely to pose problems for African States that signed onto the 1979 General Assembly's UN Convention on the Elimination of All forms of Discrimination Against Women (CEDAW). Article 2 (f) of the Convention imposes an obligation on signatory states to modify or abolish existing laws, regulations, customs and practices that constitute discrimination against women. Even in constitutional systems where the equality clause is all-encompassing or does not exempt any type of discrimination, a surviving wife might still have problems in challenging customary law on constitutional grounds, for instance against the actions of her deceased husband's relatives. They (the widow's in-laws) could argue that fundamental human rights have only a vertical and not a horizontal application. In other words, such rights apply only to actions brought by individuals against the state but not to actions between private persons. This is a concededly controversial issue (Nwabueze, 2007), and means that a surviving wife's constitutional remedies are very uncertain.

\section{Dr Remigius N Nwabueze}

City Solicitors' Educational Trust Lecturer in Property Law at the School of Law, University of Southampton; Leverhulme Research Fellow; Visiting Fellow of the Institute of Advanced Legal Studies, University of London

\section{REFERENCES}

Macpherson, C B, The Political Theory of Possessive Individualism: Hobbes to Locke (Oxford: Oxford University Press, 1962)

Moses, T "Family Abandons Corpse, Fights Widow for Property" Daily Champion, Nigeria (newspaper), November 20, 2005.

Nwabueze, R N, Biotechnology and the Challenge of Property: Property Rights in Dead Bodies, Body Parts and Genetic Information (Aldershot: Ashgate Publishing, 2007).

Nwabueze, RN "Dead Bodies in Nigerian Jurisprudence" (2007) 51 Journal of African Law 117-50.

Nwabueze, RN “The Dynamics and Genius of Nigeria's Indigenous Legal Order” (2002) 1 Indigenous Law Journal 153-99.

Richardson, Ruth "Human Dissection and Organ Donation: a Historical and Social Background" (2006) 11 Mortality 151-65.

Stamp, P "Burying Otieno: the Politics of Gender and Ethnicity in Kenya” (1991) 16 Signs 808-45. 